\title{
GMR
}

\section{Genetic variability of a Brazilian Capsicum frutescens germplasm collection using morphological characteristics and SSR markers}

\author{
S.I.C. Carvalho ${ }^{1,2}$, L.B. Bianchetti ${ }^{3}$, C.F. Ragassi ${ }^{2}$, C.S.C. Ribeiro ${ }^{2}$, \\ F.J.B. Reifschneider ${ }^{4}$, G.S.C. Buso ${ }^{3}$ and F.G. Faleiro ${ }^{5}$ \\ ${ }^{1}$ Faculdade de Agronomia e Medicina Veterinária, \\ Universidade de Brasília, Brasília, DF, Brasil \\ ${ }^{2}$ Embrapa Hortaliças, Brasília, DF, Brasil \\ ${ }^{3}$ Embrapa Recursos Genéticos e Biotecnologia, Brasília, DF, Brasil \\ ${ }^{4}$ Embrapa Relações Internacionais, Brasília, DF, Brasil \\ ${ }^{5}$ Embrapa Cerrados, Brasília, DF, Brasil \\ Corresponding author: S.I.C. Carvalho \\ E-mail: sabrina.carvalho@embrapa.br / sabrinacarvalho.carvalho@gmail.com
}

Genet. Mol. Res. 16 (3): gmr16039689

Received March 31, 2017

Accepted June 12, 2017

Published July 6, 2017

DOI http://dx.doi.org/10.4238/gmr16039689

Copyright (C) 2017 The Authors. This is an open-access article distributed under the terms of the Creative Commons Attribution ShareAlike (CC BY-SA) 4.0 License.

\begin{abstract}
Characterization studies provide essential information for the conservation and use of germplasm in plant breeding programs. In this study, 103 Capsicum frutescens L. accessions from the Active Germplasm Bank of Embrapa Hortaliças, representative of all five Brazilian geographic regions, were characterized based on morphological characteristics and microsatellite (or simple sequence repeat - SSR) molecular markers. Morphological characterization was carried out using 57 descriptors, and molecular characterization was based on 239 alleles from 24 microsatellite loci. From the estimates of genetic distances among accessions, based on molecular characterization, a cluster analysis was carried out, and a dendrogram
\end{abstract}

Genetics and Molecular Research 16 (3): gmr16039689 
was established. Correlations between morphological and molecular variables were also estimated. Twelve morphological descriptors were monomorphic for the set of $C$. frutescens accessions, and those with the highest degree of polymorphism were stem length (14.0 to 62.0 $\mathrm{cm}$ ), stem diameter (1.0 to $4.2 \mathrm{~cm}$ ), days to flowering (90 to 129), days to fruiting (100 to 140$)$, fruit weight ( 0.1 to $1.4 \mathrm{~g}$ ), fruit length ( 0.6 to $4.6 \mathrm{~cm})$, and fruit wall thickness $(0.25$ to $1.5 \mathrm{~mm})$. The polymorphism information content for the SSR loci varied from 0.36 (EPMS 417) to 0.75 (CA49), with an overall mean of 0.57 . The correlation value between morphological and molecular characterization data was 0.6604 , which was statistically significant. Fourteen accessions were described as belonging to the morphological type tabasco, 85 were described as malagueta, and four were malaguetinha, a morphological type confirmed in this study. The typical morphological pattern of malagueta was described. Six similarity groups were established for C. frutescens based on the dendrogram and are discussed individually. The genetic variability analyzed in the study highlights the importance of characterizing genetic resources available for the development of new $C$. frutescens cultivars with the potential for various niche markets.

Key words: Peppers; Polymorphism; Microsatellites; Descriptors; Germplasm bank; Multivariate analysis

\section{INTRODUCTION}

Peppers belong to the family Solanaceae and the genus Capsicum, which contains approximately 35 taxa (species and varieties), among which 30 are wild and five are domesticated: Capsicum chinense Jacq, C. frutescens L., C. annuum L. var. annuиm, $C$. baccatum L. var. pendulum (Willd.) Eshbaugh, and C. pubescens Ruiz et Pav (Eshbaugh, 1980). Three of the domesticated species, C. annuum, C. chinense, and C. frutescens, form a closely related group that evolved in the lowlands of the tropics of Latin America and the Caribbean, with $C$. annuum predominating in Mexico, C. frutescens in the Caribbean, and $C$. chinense in the Amazon basin (Pickersgill et al., 1979).

The most common morphological types of $C$. frutescens, one of the most cultivated Capsicum species in Brazil, are malagueta pepper (in Brazil) and tabasco pepper (in Mexico and the USA). The main difference between these types is the size and color of the fruit, which varies according to the ripening stage. For malagueta, color changes directly from green (unripe fruit) to red (ripe fruit) and, in some cases it steps by an intermediate stage that occurs before the fully ripe fruit, corresponding to a light red color. For tabasco, the color transition has more steps, beginning with light green, followed by yellow, orange, and light red that deepens to red (ripe fruit). Furthermore, the two types differ in fruit size: the fruits range from 1 to $3 \mathrm{~cm}$ long and 0.4 to $0.5 \mathrm{~cm}$ wide for malagueta, whereas, for tabasco, they range from 2.5 to $5 \mathrm{~cm}$ long and are 0.5 $\mathrm{cm}$ wide (Carvalho et al., 2014). Producers have mentioned a third morphological type, named malaguetinha (small malagueta), but the literature on this type is very rare. Characteristics of malaguetinha are small-sized, highly pungent fruits presenting upright position, elongated or short cylindrical shape, red color when ripe (Ribeiro et al., 2008; Rêgo et al., 2012).

Genetics and Molecular Research 16 (3): gmr16039689 
In Brazil, the morphological type malagueta is mainly grown in small family-run farms (Ribeiro et al., 2008), especially in the States of Minas Gerais, Bahia, Goiás, Sergipe, and Roraima, the latter located on the northern edge of the Brazilian Amazon basin. The $C$. frutescens (malagueta pepper) and C. chinense (murupi pepper and olho-de-peixe pepper) peppers are the morphological types that are most traditionally consumed and shared by the indigenous communities of the Brazilian Amazon basin due to the high pungency of their fruits (Barbosa et al., 2002, 2010).

Plants of $C$. frutescens are typically erect, and fruits are erect, soft-fleshed, and deciduous. They are usually small and conical, have very thin walls, are red when ripe, have high capsaicin content and are sold fresh or dried in markets or processed into liquid sauces, preserves, jams, and pastes (Ribeiro et al., 2008).

The genetic variability of $C$. frutescens has been little explored in plant breeding programs. Consequently, few cultivars of this species are commercialized worldwide: 'tabasco', 'green-leaf tabasco', 'malagueta', and 'siling labuyo' (DeWitt and Bosland, 2009). Besides, there are many misidentifications and many cultivars listed in seed catalogs as $C$. frutescens are in fact C. annuum.

Many Brazilian farmers who cultivate malagueta select fruits that they have produced for seed extraction aiming the next planting. These seeds often have poor phytosanitary and physiological quality and a slow and less uniform germination, culminating in low crop productivity. Furthermore, malagueta pepper cultivars found in the Brazilian market have a poor uniformity of plant, fruit, and productivity, reinforcing shortage of malagueta pepper cultivars with superior plant and fruit characteristics (Ribeiro et al., 2008).

The development of new malagueta pepper cultivars and hybrids with desirable agronomic and industrial characteristics depends on the genetic variability available. Embrapa Hortaliças Capsicum Active Germplasm Bank (AGB) located in Brasília, Distrito Federal, Brazil, was started 36 years ago and has consolidated ex situ conservation strategies including the characterization of the variability found in the genus Capsicum. Currently, the AGB has over 4000 accessions, comprising the five Capsicum domesticated species and dozens semi-domesticated and wild species from various regions of Brazil and other countries. Among all conserved accessions, the AGB has 103 accessions identified as $C$. frutescens.

The aim of this study was to evaluate the genetic variability of 103 C. frutescens accessions from the Capsicum AGB, based on morphological characteristics and microsatellite molecular markers, thus enhancing knowledge regarding the $C$. frutescens genetic variability available for breeding programs.

\section{MATERIAL AND METHODS}

\section{Genetic material}

A total of 103 C. frutescens accessions of Embrapa's AGB from the five different Brazilian regions were morphologically evaluated: North, Northeast, Center-West, Southeast, and South. For the molecular analysis, accessions from other species were included: 15 C. chinense, one C. baccatum var. pendulum, one C. praetermissum, two $C$. annuиm var. annuит, and one C. annuит var. glabriusculum, resulting in a total of 123 accessions (Table 1).

Genetics and Molecular Research 16 (3): gmr16039689 
Table 1. Capsicum accessions (123) of Embrapa Hortaliças Active Germplasm Bank used for a study on the Capsicum frutescens variability.

\begin{tabular}{|c|c|c|c|c|}
\hline & $\mathrm{CNPH}$ & Origin (region) & Morphological type & Species \\
\hline 1 & 63 & Southeast & Malagueta & C. frutescens \\
\hline 2 & 287 & Center-West & Malagueta & C. frutescens \\
\hline 3 & 595 & Southeast & Malagueta & C. frutescens \\
\hline 4 & 597 & Center-West & Malagueta & C. frutescens \\
\hline 5 & 1386 & Northeast & Malagueta & C. frutescens \\
\hline 6 & 2631 & Southeast & Malagueta & C. frutescens \\
\hline 7 & 2744 & North & Malagueta & C. frutescens \\
\hline 8 & 2841 & North & Malagueta & C. frutescens \\
\hline 9 & $2866 \mathrm{~A}$ & North & Malagueta & C. frutescens \\
\hline 10 & $2866 \mathrm{~B}$ & North & Similar to Habanero & C. chinense \\
\hline 11 & 2869 & North & Malagueta & C. frutescens \\
\hline 12 & 2870 & North & Malagueta & C. frutescens \\
\hline 13 & 2871 & North & Similar to Malagueta & C. chinense \\
\hline 14 & 3241 & Center-West & Malagueta & C. frutescens \\
\hline 15 & 3257 & Northeast & Malagueta & C. frutescens \\
\hline 16 & 3286 & North & Malagueta & C. frutescens \\
\hline 17 & 3349 & Southeast & Malagueta & C. frutescens \\
\hline 18 & 3374 & Center-West & Malagueta & C. frutescens \\
\hline 19 & 3399 & North & Malagueta & C. frutescens \\
\hline 20 & 3410 & Center-West & Malagueta & C. frutescens \\
\hline 21 & 3414 & Southeast & Malagueta & C. frutescens \\
\hline 22 & 3440 & Southeast & Malagueta & C. frutescens \\
\hline 23 & 3446 & Southeast & Malagueta & C. frutescens \\
\hline 24 & 3448 & North & Malagueta & C. frutescens \\
\hline 25 & 3453 & North & Similar to Malagueta & C. chinense \\
\hline 26 & 3462 & North & Malagueta & C. frutescens \\
\hline 27 & 3470 & North & Malagueta & C. frutescens \\
\hline 28 & 3484 & North & Malagueta & C. frutescens \\
\hline 29 & 3499 & North & Malagueta & C. frutescens \\
\hline 30 & $3535 \mathrm{~A}$ & North & Malagueta & C. frutescens \\
\hline 31 & $3535 \mathrm{~B}$ & North & Similar to Murupi & C. chinense \\
\hline 32 & 3539 & North & Malagueta & C. frutescens \\
\hline 33 & 3546 & North & Malagueta & C. frutescens \\
\hline 34 & 3550 & North & Malagueta & C. frutescens \\
\hline 35 & $3606 \mathrm{~A}$ & North & Malaguetinha & C. frutescens \\
\hline 36 & $3606 \mathrm{~B}$ & North & Similar to Malaguetinha & C. chinense \\
\hline 37 & 3612 & North & Malagueta & C. frutescens \\
\hline 38 & 3621 & Southeast & Malagueta & C. frutescens \\
\hline 39 & 3630 & USA & Malagueta & C. frutescens \\
\hline 40 & 3645 & Northeast & Malagueta & C. frutescens \\
\hline 41 & 3646 & Northeast & Malagueta & C. frutescens \\
\hline 42 & 3647 & Northeast & Malagueta & C. frutescens \\
\hline 43 & 3648 & Northeast & Malagueta & C. frutescens \\
\hline 44 & 3649 & Northeast & Malagueta & C. frutescens \\
\hline 45 & 3667 & Southeast & Malagueta & C. frutescens \\
\hline 46 & 3696 & Center-West & Malagueta & C. frutescens \\
\hline 47 & 3697 & Southeast & Malagueta & C. frutescens \\
\hline 48 & 3698 & Center-West & Malagueta & C. frutescens \\
\hline 49 & 3715 & North & Malagueta & C. frutescens \\
\hline 50 & 3716 & North & Malagueta & C. frutescens \\
\hline 51 & 3746 & - & Malagueta & C. frutescens \\
\hline 52 & 3804 & Center-West & Malagueta & C. frutescens \\
\hline 53 & 3805 & Center-West & Malagueta & C. frutescens \\
\hline 54 & 3806 & Center-West & Malagueta & C. frutescens \\
\hline 55 & 3813 & Center-West & Malagueta & C. frutescens \\
\hline 56 & 3815 & Center-West & Malagueta & C. frutescens \\
\hline 57 & 3816 & Center-West & Malagueta & C. frutescens \\
\hline 58 & 3818 & Center-West & Malagueta & C. frutescens \\
\hline 59 & 3819 & Southeast & Malagueta & C. frutescens \\
\hline 60 & 3820 & Northeast & Malagueta & C. frutescens \\
\hline 61 & 3821 & Northeast & Malagueta & C. frutescens \\
\hline 62 & 3835 & Southeast & Malagueta & C. frutescens \\
\hline 63 & 3847 & Southeast & Malagueta & C. frutescens \\
\hline 64 & 3861 & Northeast & Tabasco & C. frutescens \\
\hline 65 & 3880 & North & Malagueta & C. frutescens \\
\hline
\end{tabular}

Continued on next page

Genetics and Molecular Research 16 (3): gmr16039689 


\begin{tabular}{|c|c|c|c|c|}
\hline & CNPH & Origin (region) & Morphological type & Species \\
\hline 66 & 3885 & North & Malagueta & C. frutescens \\
\hline 67 & 3891 & North & Malagueta & C. frutescens \\
\hline 68 & 3894 & North & Malaguetinha & C. frutescens \\
\hline 69 & 3906 & Center-West & Malagueta & C. frutescens \\
\hline 70 & 3932 & North & Malagueta & C. frutescens \\
\hline 71 & 3944 & Northeast & Tabasco & C. frutescens \\
\hline 72 & 3984 & South & Malagueta & C. frutescens \\
\hline 73 & 4005 & North & Malagueta & C. frutescens \\
\hline 74 & 4011 & Center-West & Malagueta & C. frutescens \\
\hline 75 & 4020 & Southeast & Malagueta & C. frutescens \\
\hline 76 & 4037 & North & Malaguetinha & C. frutescens \\
\hline 77 & 4052 & Northeast & Malagueta & C. frutescens \\
\hline 78 & 4069 & Center-West & Malagueta & C. frutescens \\
\hline 79 & 4082 & Center-West & Dedo-de-moça & C. baccatum var. pendulum \\
\hline 80 & 4083 & Center-West & Malagueta & C. frutescens \\
\hline 81 & $4084 \mathrm{~A}$ & Center-West & Malagueta & C. frutescens \\
\hline 82 & $4084 \mathrm{~B}$ & Center-West & Malagueta & C. frutescens \\
\hline 83 & 4085 & Center-West & Malagueta & C. frutescens \\
\hline 84 & 4095 & South & Malagueta & C. frutescens \\
\hline 85 & 4105 & Center-West & Malagueta & C. frutescens \\
\hline 86 & 4138 & North & Malagueta & C. frutescens \\
\hline 87 & $4154 \mathrm{~A}$ & Southeast & Malagueta & C. frutescens \\
\hline 88 & $4154 \mathrm{~B}$ & Southeast & Similar to Malagueta & C. chinense \\
\hline 89 & 4161 & Southeast & Tabasco & C. frutescens \\
\hline 90 & 4184 & North & Malagueta & C. frutescens \\
\hline 91 & 4191 & North & Malagueta & C. frutescens \\
\hline 92 & 4195 & North & Malagueta & C. frutescens \\
\hline 93 & 4212 & Center-West & Ornamental & C. annuum var. glabriusculum \\
\hline 94 & 4224 & Center-West & Malagueta & C. frutescens \\
\hline 95 & 4231 & Center-West & Malagueta & C. frutescens \\
\hline 96 & 4237 & Center-West & Malagueta & C. frutescens \\
\hline 97 & 4263 & Northeast & Tabasco & C. frutescens \\
\hline 98 & 4264 & Northeast & Tabasco & C. frutescens \\
\hline 99 & 4265 & Northeast & Tabasco & C. frutescens \\
\hline 100 & 4266 & Northeast & Tabasco & C. frutescens \\
\hline 101 & 4267 & Northeast & Tabasco & C. frutescens \\
\hline 102 & 4268 & Northeast & Tabasco & C. frutescens \\
\hline 103 & 4269 & Northeast & Tabasco & C. frutescens \\
\hline 104 & 4270 & Northeast & Tabasco & C. frutescens \\
\hline 105 & 4271 & Northeast & Tabasco & C. frutescens \\
\hline 106 & 4272 & Northeast & Tabasco & C. frutescens \\
\hline 107 & 4273 & Northeast & Tabasco & C. frutescens \\
\hline 108 & 4274 & Center-West & Bode & C. chinense \\
\hline 109 & 4283 & North & Malagueta & C. frutescens \\
\hline 110 & 4304 & North & Malagueta & C. frutescens \\
\hline 111 & 4353 & North & Malaguetinha & C. frutescens \\
\hline 112 & 4364 & North & Malagueta & C. frutescens \\
\hline 113 & 30062 & Center-West & Jalapeño & C. апnиит var. аппиит \\
\hline 114 & 40013 & North & Bell pepper & C. annuum var. annuum \\
\hline 115 & 3825 & Southeast & Cumari & C. praetermissum \\
\hline 116 & 4315 & North & Olho de peixe & C. chinense \\
\hline 117 & 4316 & North & Similar to Malagueta & C. chinense \\
\hline 118 & 4325 & North & Similar to Malagueta & C. chinense \\
\hline 119 & 4327 & North & Similar to Habanero & C. chinense \\
\hline 120 & 4328 & North & Similar to Bode & C. chinense \\
\hline 121 & $4332 \mathrm{~A}$ & North & Similar to Cayenne & C. chinense \\
\hline 122 & 4360 & North & Murupi & C. chinense \\
\hline 123 & 4361 & North & Similar to Tabasco & C. chinense \\
\hline
\end{tabular}

Approximately 45 days after sowing, five seedlings per accession were transplanted to the soil in a greenhouse in the experimental area of Embrapa Vegetables, Brasília, DF, Brazil, located at $15^{\circ} 56^{\prime} \mathrm{S}, 48^{\circ} 08^{\prime} \mathrm{W}$, and $998 \mathrm{~m}$ in altitude; plants were kept from September 2009 to March 2010, spaced $1.5 \mathrm{~m}$ between rows and $0.60 \mathrm{~m}$ within a row. Drip irrigation was used

Genetics and Molecular Research 16 (3): gmr16039689 
in the trial, and plant cultivation followed technical recommendations for the cultivation of Capsicum (Ribeiro et al., 2008).

\section{Morphological characterization}

Morphological characterization was carried out using 53 descriptors usually recommended for Capsicum (International Plant Genetic Resources Institute - IPGRI, 1995) and four descriptors were added for this study: fruit position, pungency, aroma, and segregation. The set of descriptors included 17 passport/vegetative part descriptors, 16 inflorescence/seed descriptors, and 24 fruit descriptors (Table 2).

\begin{tabular}{|c|c|c|}
\hline Passport/vegetative part & Inflorescence/seed & Fruit \\
\hline Origin & Male sterility & Fruit persistence \\
\hline Species & Calyx margin & Number of locules \\
\hline Plant height & Number of flowers/axil & Fruit wall thickness \\
\hline Plant width & Calyx pigmentation & Fruit pedicel length \\
\hline Leaf color & Flower position & Fruit weight \\
\hline Leaf shape & Stigma exsertion & Fruit width \\
\hline Leaf density & Calyx annular constriction & Pungency \\
\hline Stem shape & Corolla spot color & Fruit shape \\
\hline Stem color & Anther color & Days to fruiting \\
\hline Stem length & Filament color & Fruit color at immature stage \\
\hline Stem diameter & Corolla color & Fruit color at mature stage \\
\hline Branching habit & Days to flowering & Placenta length \\
\hline Nodal anthocyanin & Corolla shape & Aroma \\
\hline Growth habit & Seed color & Fruit length \\
\hline Tillering & Number of seeds/fruit & Fruit blossom end appendage \\
\hline Leaf pubescence & Seed surface & Varietal mixture condition \\
\hline \multirow[t]{8}{*}{ Stem pubescence } & & Segregation \\
\hline & & Fruit shape at pedicel attachment \\
\hline & & Fruit position \\
\hline & & Anthocyanin spot \\
\hline & & Neck at base of fruit \\
\hline & & Fruit shape at blossom end \\
\hline & & Cross-sectional corrugation \\
\hline & & Fruit surface \\
\hline
\end{tabular}

\section{Molecular characterization}

Samples of leaflets from two plants of each accession were collected individually for DNA extraction using the cetyltrimethylammonium bromide (CTAB) $2 \%$ protocol, with modifications. The concentration of DNA in each tube was estimated by electrophoresis on a $1.0 \%(\mathrm{w} / \mathrm{v})$ agarose gel by comparing the fluorescence intensity of each sample stained with ethidium bromide with different concentrations of lambda DNA standards. Each sample was diluted to $3.0 \mathrm{ng} / \mu \mathrm{L}$.

The amplification reactions applied to the DNA samples from two plants from each of the 123 accessions were carried out using 24 pairs of SSR primers, 19 from Carvalho et al. (2015) and Buso et al. (2016) (CA19, CA20, CA26, CA27, CA29, CA41, CA49, CA52, CA56, CA62, CA79, CA88, CA96, CA131, CA159, CA167, CA172, CA174, and CA178) and five from Nagy et al. (2007) (EPMS 331, EPMS 376, EPMS 386, EPMS 417, and GPMS 112). The reaction was carried out in a total volume of $10 \mu \mathrm{L}$ containing $10 \%(\mathrm{v} / \mathrm{v})$ reaction buffer (10 mM Tris-HCl, $\mathrm{pH} 8.3,50 \mathrm{mM} \mathrm{KCl}, 1.5 \mathrm{mM} \mathrm{MgCl}_{2}$ ), 1 U Taq DNA polymerase, 
$200 \mu \mathrm{M}$ of each dNTP, $0.2 \mathrm{mg} / \mathrm{mL}$ bovine serum albumin, $0.15 \mu \mathrm{M}$ of each primer labeled with 6-FAM (blue), HEX (green), or NED (yellow) fluorescence and 3 ng DNA template. The reactions were carried out in a PT-100 thermal controller (MJ Research, Waltham, MA, USA) using the following conditions: $15 \mathrm{~min}$ at $95^{\circ} \mathrm{C}$ (one cycle); $0.5 \mathrm{~min}$ at $95^{\circ} \mathrm{C}, 1.30 \mathrm{~min}$ at $56^{\circ} \mathrm{C}$, $1 \mathrm{~min}$ at $72^{\circ} \mathrm{C}$ (30 cycles); and $50 \mathrm{~min}$ at $60^{\circ} \mathrm{C}$ (one cycle).

The 123 accessions were genotyped using an ABI 3730 automated sequencer (Applied Biosystems, Foster City, CA, USA). Samples were prepared by the polymerase chain reaction (PCR) by mixing $1 \mu \mathrm{L}$ reaction with $10 \mu \mathrm{L}$ denaturing agent formamide (HiDi) and $1 \mu \mathrm{L}$ of the molecular weight standard (ROX). The mixture was then denatured for $5 \mathrm{~min}$ at $95^{\circ} \mathrm{C}$.

After passage through the sequencer, the fluorescence peaks and the alleles detected to perform the genotyping were demarcated manually with the help of the GeneMapper software version 4.1 (Applied Biosystems). The allele sizes were rounded using the AlleloBin software. A spreadsheet was then created that identified each plant analyzed and the respective alleles present in each of the analyzed 24 SSR loci.

The genetic distances obtained from the microsatellite markers were calculated with the help of the Genes software based on the following formula:

GDij = 1 - (NCL/TNL), where GDij = genetic distance between $\mathrm{i}$ and $\mathrm{j}$ accessions; $\mathrm{NCL}=$ number of coincident loci; $\mathrm{TNL}=$ total number of loci.

The NCL is the sum of the allelic coincidences of each analyzed locus, and each coincidence can assume a value of 1 (two coincident alleles), 0.5 (one coincident allele), or 0 (no coincident allele).

The matrix of genetic distances was used to carry out the cluster analysis with the dendrogram using the unweighted pair group mean averaging (UPGMA) method as the clustering criterion and the SAS and Statistica programs.

The correlation and its significance ( $t$-test) were estimated between the calculated genetic distances based on the SSR molecular markers and the calculated distances based on the set of morphological descriptors through a simple correlation analysis using Pearson's correlation coefficient, with the help of the statistical program Genes.

\section{RESULTS}

Of the 57 descriptors used in the morphological characterization, 12 descriptors were monomorphic for the 103 C. frutescens accessions characterized: stem pubescence (sparse), leaf shape (ovate), leaf pubescence (sparse), flower position (erect), corolla color (white-green), corolla spot color (spot absent), calyx pigmentation (absent), fruit blossom end appendage (absent), neck at base of fruit (absent), seed color (deep yellow), seed surface (smooth), and male sterility (absent). Among the $C$. frutescens accessions evaluated, 14 were described as belonging to the morphological type tabasco, 85 as malagueta, and four as malaguetinha, a morphological type confirmed in this study. To describe the typical morphological type malagueta, the most frequent characteristics of the 85 accessions considering 55 of the 57 morphological descriptors (excluding origin and species), are presented in Table 3.

The morphological descriptors with the highest degree of polymorphism (i.e., presenting the largest number of classes or categories), for the $103 \mathrm{C}$. frutescens accessions, were the following: stem length (14 to $62 \mathrm{~cm}$ ), stem diameter (1 to $4.2 \mathrm{~cm}$ ), days to flowering (90 to 129 days), days to fruiting (100 to 140 days), fruit weight ( 0.1 to $1.4 \mathrm{~g}$ ), fruit length (0.6 to $4.6 \mathrm{~cm})$, and fruit wall thickness $(0.25$ to $1.5 \mathrm{~mm})$.

Genetics and Molecular Research 16 (3): gmr16039689 
Table 3. Morphological descriptors for Capsicum and the most frequent forms presented by 85 accessions of malagueta peppers (Capsicum frutescens).

\begin{tabular}{|c|c|c|}
\hline Descriptor & Most frequent form & Occurrence of the most frequent form (\%) \\
\hline Stem color & Green & 98 \\
\hline Nodal anthocyanin & Green & 69 \\
\hline Stem shape & Cylindrical & 73 \\
\hline Stem pubescence & Sparse & 100 \\
\hline Plant height $(\mathrm{cm})$ & $100-125$ & 52 \\
\hline Growth habit & Intermediate & 75 \\
\hline Plant width $(\mathrm{cm})$ & $100-125$ & 42 \\
\hline Stem length $(\mathrm{cm})$ & $15-30$ & 40 \\
\hline Stem diameter $(\mathrm{cm})$ & $1-2$ & 76 \\
\hline Branching habit & Dense & 70 \\
\hline Tillering & Intermediate & 50 \\
\hline Leaf density & Dense & 70 \\
\hline Leaf color & Dark green & 68 \\
\hline Leaf shape & Ovate & 100 \\
\hline Leaf pubescence & Sparse & 100 \\
\hline Days to flowering & Up to 100 & 42 \\
\hline Number of flowers/axil & 2 & 59 \\
\hline Flower position & Erect & 100 \\
\hline Corolla color & White-green & 100 \\
\hline Corolla spot color & Absent & 100 \\
\hline Corolla shape & Campanulated & 53 \\
\hline Anther color & Pale blue & 86 \\
\hline Filament color & Light purple & 75 \\
\hline Stigma exsertion & Exserted & 95 \\
\hline Calyx pigmentation & Absent & 100 \\
\hline Calyx margin & Entire & 95 \\
\hline Calyx annular constriction & Absent & 91 \\
\hline Days to fruiting & $>122$ & 38 \\
\hline Fruit color at immature stage & Green & 99 \\
\hline Fruit position & Erect & 98 \\
\hline Fruit color at mature stage & Red & 47 \\
\hline Fruit shape & Elongated & 94 \\
\hline Fruit length $(\mathrm{cm})$ & $2-3$ & 63 \\
\hline Fruit width $(\mathrm{cm})$ & $0.5-0.7$ & 65 \\
\hline Fruit weight $(\mathrm{g})$ & $0.5-0.7$ & 43 \\
\hline Fruit pedicel length $(\mathrm{cm})$ & $2-3$ & 76 \\
\hline Fruit wall thickness $(\mathrm{mm})$ & $0.5-0.8$ & 56 \\
\hline Fruit shape at pedicel attachment & Obtuse & 74 \\
\hline Neck at base of fruit & Absent & 100 \\
\hline Fruit shape at blossom end & Blunt & 43 \\
\hline Fruit blossom end appendage & Absent & 100 \\
\hline Cross-sectional corrugation & Slight corrugated & 93 \\
\hline Number of locules & 2 & 95 \\
\hline Fruit surface & Semi-wrinkled & 78 \\
\hline Fruit persistence & Persistent & 61 \\
\hline Placenta length & $>1 / 2$ Fruit length & 99 \\
\hline Pungency & Highly spicy & 89 \\
\hline Aroma & Low & 89 \\
\hline Seed color & Deep yellow & 100 \\
\hline Seed surface & Smooth & 100 \\
\hline Number of seeds/fruit & $<20$ & 69 \\
\hline Segregation & Absent & 100 \\
\hline Varietal mixture condition & Absent & 93 \\
\hline Male sterility & Absent & 100 \\
\hline Anthocyanin spot & Absent & 99 \\
\hline
\end{tabular}

The 24 SSR loci used for molecular characterization generated 239 alleles that allowed the discrimination of $C$. frutescens among the 123 accessions with a dissimilarity value of 0.75 (Figure 1). For the SSR loci analyzed in this study, the PIC ranged from 0.36 (EPMS 417; Nagy et al., 2007) to 0.75 (CA49; Carvalho et al., 2015), with an overall mean of 0.57. Of the 24 SSR loci, 18 (75\%) presented a PIC greater than 0.5, highlighting the presence of genetic variability among the analyzed accessions. Null distances were only obtained between

Genetics and Molecular Research 16 (3): gmr16039689 
replicates of plants from the same accession, eliminating the possibility of duplicates. The correlation between the morphological and molecular characterization data had a value of 0.6604 , which was significant ( $t$-test $1 \%)$.

The dendrogram based on molecular data (Figure 1) shows the discrimination among species. C. praetermissum (CNPH 3825) appeared to be the most distinct species (dissimilarity greater than 0.90 compared with the other accessions), followed by $C$. chinense (dissimilarity around 0.83), C. baccatum var. pendulum (CNPH 4082, 0.80 dissimilarity), C. annuиm (CNPH 30062, CNPH 4212, and CNPH 40013, dissimilarity slightly below 0.80), and finally, the formation of a large group of $C$. frutescens ( 0.75 dissimilarity).

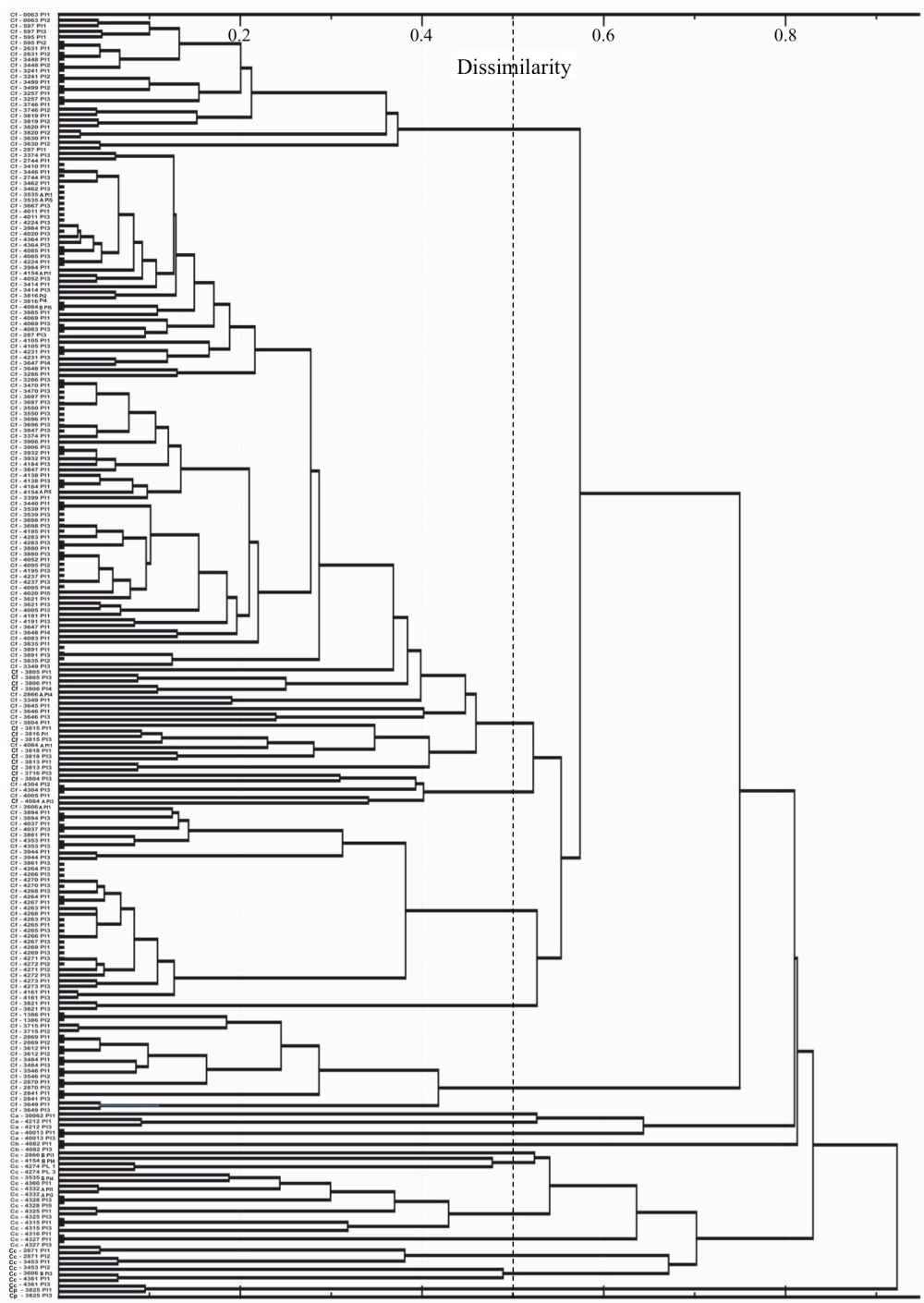

Figure 1. Genetic variability of Capsicum spp assessed using 24 microsatellite loci $(\mathrm{Ca}-$ Capsicum annuum, $\mathrm{Cb}$ C. baccatum var. pendulum, $\mathrm{Cc}-$ C. chinense, $\mathrm{Cf}-$ C. frutescens, and $\mathrm{Cp}-$ C. praetermissum). 
By establishing a cut-off point in the genetic dissimilarity value equivalent to 0.5 (Figure 1, vertical dotted line), the 103 C. frutescens accessions were divided into six groups that varied in number from one accession (Group 5, corresponding to $0.97 \%$ of the C. frutescens accessions) to 60 accessions (Group 2, 58.2\% of the $C$. frutescens accessions). Group 6 was the most dissimilar (dissimilarity around 0.75 ), followed by Group 1 (dissimilarity around 0.60 ). Groups 2 and 3 were separated from Groups 4 and 5 (by approximately 0.55 dissimilarity), and the distance from Group 2 to Group 3, as well as from Group 4 to Group 5, was slightly above (0.50 dissimilarity). Two accessions (CNPH 3804 and CNPH 4005) had samples clustered into two different groups (Groups 2 and 3, for both cases). These accessions were considered as belonging to both groups.

Group 6, consisting of nine accessions (CNPH 1386, CNPH 2841, CNPH 2869, CNPH 2870, CNPH 3484, CNPH 3546, CNPH 3612, CNPH 3649, and CNPH 3715) from the North and Northeast regions, was the only group that reflected a relationship with the geographical origin, containing the highest proportion of accessions from the North region among all the established groups. The proportion of accessions from the North region accounted for $77.8 \%$ of the accessions in Group 6, while this proportion was 32\% in the set of 103 C. frutescens accessions studied. Nineteen morphological characteristics were shared among the genotypes in Group 6, demonstrating the genetic similarity among them. Group 6 exhibited the highest concentration of accessions with erect growth habit $(88.9 \%$ accessions in the group), a characteristic present only in $19.4 \%$ of the $C$. frutescens accessions studied, and fruits with low persistence (88.9\% of the accessions in Group 6), a characteristic shared with the accessions in Group 4 (77.8\% of the Group 4 accessions).

Group 1 consisted of 12 accessions, 11 of which (CNPH 63, CNPH 595, CNPH 597, CNPH 2631, CNPH 3448, CNPH 3241, CNPH 3257, CNPH 3499, CNPH 3746, CNPH 3819 , and CNPH 3820) exhibited a morphological pattern similar to "malagueta", but one accession (CNPH 3630) exhibited tabasco characteristics. Group 1 accessions shared nine morphological characteristics, all with an occurrence of $100 \%$. The main discriminatory characteristics of this group in relation to the others were a high concentration of accessions with early flowering ( $75 \%$ of the group accessions) and early fruiting (66\% of the group accessions) beginning at 30 and 60 days after transplantation, respectively; fruits with intermediate persistence $(50 \%$ of the group accessions), i.e., medium ease of detachment of the ripe fruit, and especially, a largest variation in values for the aroma of the fruits, which ranged from low to high, while this value was consistently low in the other groups.

Accessions in Groups 2 and 3 shared 21 morphological characteristics and presented the most dissimilar patterns in comparison to the typical "malagueta" (Table 3). Both groups contained at least one accession with the following unique characteristics, unusual for $C$. frutescens: presence of calyx annular constriction (CNPH 3804, CNPH 3805, CNPH 3806, CNPH 3813, CNPH 3815, and CNPH 3818, corresponding to 7.8\% of the accessions within the two groups), yellow-ripe fruits (CNPH 3804, CNPH 3813, and CNPH 3818, 2.9\% of the accessions), and rectangular fruits (CNPH 3804). Group 2 was the largest group (Figure 1), formed by 60 accessions (CNPH 0287 to $\mathrm{CNPH} 4364$ ) that shared nine morphological characteristics. In a large portion of their accessions, Groups 2 and 3 had a similar dense branching habit occurrence ( 93.3 and $80 \%$, respectively), as well as dense leaf density ( 93.3 and $80 \%$, respectively).

Group 2 differed from all others for presenting the highest concentration of accessions with dark green leaves (86.6\% compared with $61 \%$ among the 103 C. frutescens accessions),

Genetics and Molecular Research 16 (3): gmr16039689 
and the only orange (CNPH 3805 and CNPH 3806) and triangular (CNPH 3805, CNPH 3815, and CNPH 3818) fruits.

Group 3 consisted of five accessions (CNPH 3716, CNPH 3804, CNPH 4005, CNPH 4084B and CNPH 4304). Unexpectedly, one of the replicates of CNPH 3804 and CNPH 4005 was clustered in Group 2 and therefore separated by the dissimilarity value corresponding to the separation between the two groups (approximately 0.53 ). This result, although unexpected, emphasizes the genetic closeness between Groups 2 and 3. Eight characteristics were shared by Group 3 accessions. Group 3 differed from the other groups because it predominantly exhibited delayed flowering ( $40 \%$ compared with $18.4 \%$ of the $C$. frutescens accessions) and delayed fruiting ( $40 \%$ compared with $50 \%$ of the $C$. frutescens accessions), beginning at 90 and 120 days after transplantation, respectively. This group included the only accessions with plants exhibiting dark purple nodal anthocyanin (CNPH 3716 and CNPH 4304), fruits with a pendant (CNPH 4084B) and an intermediate (CNPH 3716) position, fruits with $4.1 \mathrm{~cm}$ in length (CNPH 3716), consistently longer than the mean determined for the $C$. frutescens accessions $(2.6 \mathrm{~cm})$ and the accessions with the greatest fruit wall thickness (CNPH 3716 and CNPH 4084B), ranging from 1 to $1.3 \mathrm{~mm}$, thicker than the mean determined for the $C$. frutescens accessions, $0.57 \mathrm{~mm}$.

The accessions in Groups 4 and 5 shared 13 characteristics and presented accessions with the most similar morphological pattern to the typical malagueta (50 and 63\% of the accessions belonging to each group, respectively; Figure 2).

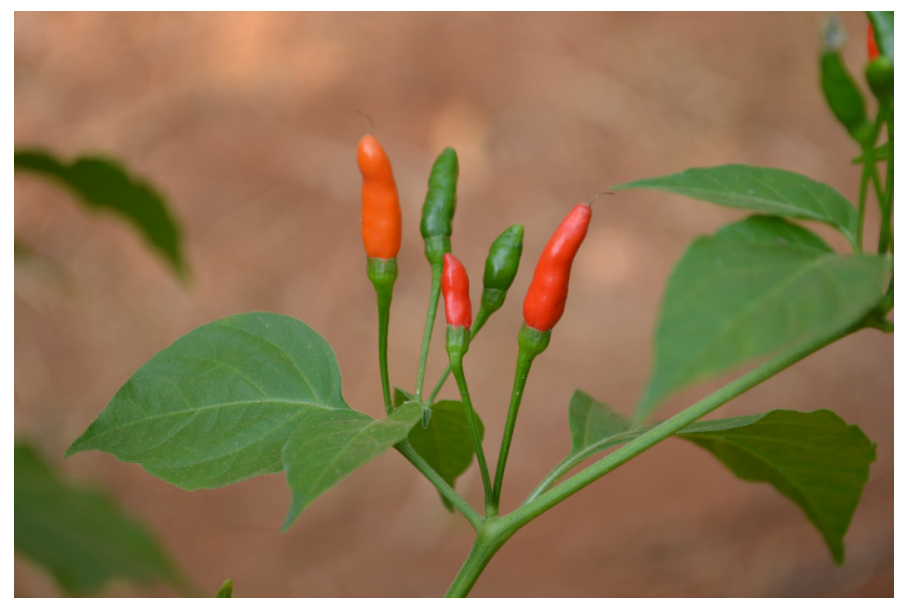

Figure 2. Capsicum frutescens fruits typical of the morphological type malagueta (accession CNPH 3894).

Group 4 consisted of 18 accessions that shared 15 characteristics. Group 4 differed from the other groups because it had the highest concentration of accessions with thick stems ( $3 \mathrm{~cm}$ in diameter compared with a mean of $1.9 \mathrm{~cm}$ for the $C$. frutescens accessions), plants with a single flower per reproductive node, purple filament, intermediate calyx margin, greenyellow fruit at the immature stage, and the highest concentration of accessions with the lowest fruit weights (16.6\% of accessions weighing less than $0.3 \mathrm{~g}$ compared with $13.6 \%$ of the C. frutescens accessions), as well as accessions with the greatest fruit weights $(77.8 \%$ of accessions with fruits weighing between 0.7 and $1.2 \mathrm{~g}$ compared with $26.2 \%$ of the set of C. frutescens accessions). The mean fruit weight among the 103 C. frutescens accessions

Genetics and Molecular Research 16 (3): gmr16039689 
was $0.58 \mathrm{~g}$. Groups 4 and 1 had the highest concentration of accessions with a plant height exceeding $150 \mathrm{~cm}$, among which $66.6 \%$ corresponded to Group 4 and $33.3 \%$ to Group 1, in contrast to the mean value of $135 \mathrm{~cm}$ determined for the set of $C$. frutescens accessions.

Two morphological types (two subgroups) composed Group 4, separated by a dissimilarity value close to 0.4 . The first subgroup (4a) comprised genotypes CNPH 3606 A, CNPH 3894, CNPH 4037, and CNPH 4353, and one of the replicates of CNPH 3861. The first four listed accessions characterize the morphological type malaguetinha (Figure 3).

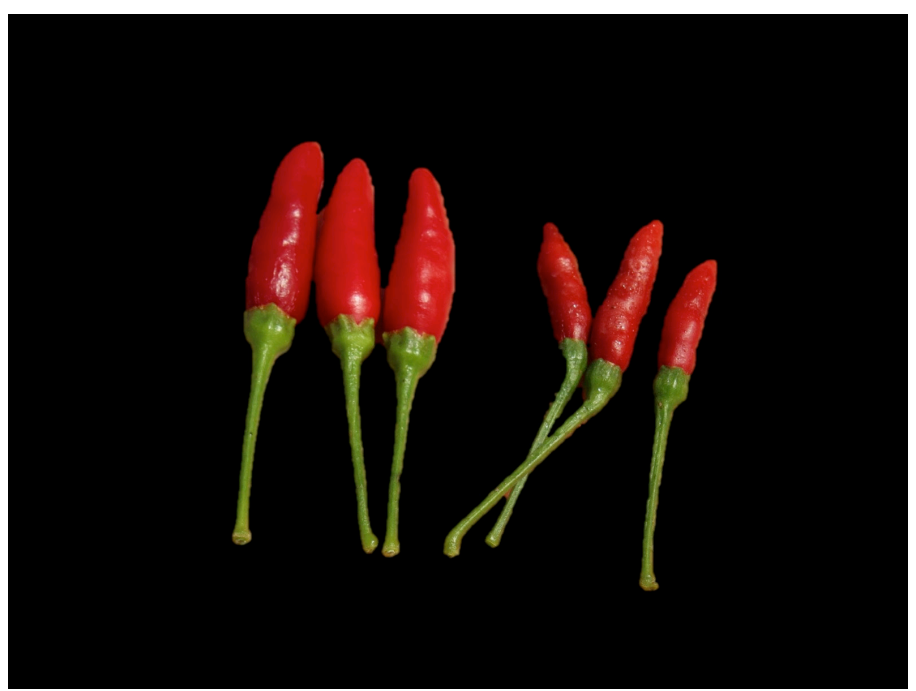

Figure 3. Capsicum frutescens fruits typical of the morphological type malagueta (accession CNPH 3820, left) and malaguetinha (accession CNPH 3894, right), with a comparatively smaller size.

One of the samples of accession CNPH 3861, which was characterized morphologically as tabasco, clustered within this subgroup. The other sample of CNPH 3861 was clustered with the immediately adjacent subgroup (4b). This second subgroup (4b) was formed by 14 accessions corresponding to the morphological type tabasco (CNPH 3861, CNPH 3944, CNPH 4161, and CNPH 4263 to CNPH 4273; Figure 4), with green-yellow immature fruit (Figure 5) and accessions with fruit weighing between 0.7 and $1.3 \mathrm{~g}(100 \%$ of the accessions in the subgroup compared with $26.2 \%$ in the total set of $C$. frutescens accessions evaluated), characteristics that differentiated them from all other studied accessions.

Group 5 consisted of only one accession (CNPH 3821). Although clustered alone, $\mathrm{CNPH} 3821$ displayed $63 \%$ of the characteristics associated with the malagueta typical morphologic pattern, but a unique shorter placenta length, $1 / 4$ to $1 / 2$ of the fruit length; in all other accessions, this trait was more than $1 / 2$ of the fruit length. Accession CNPH 3821 also exhibited other characteristics that were less common in the other accessions, such as intermediate fruit cross-section corrugation and fruit with a sunken blossom end shape (Figure 6), while most of the accessions (94.2\%) had blunt or pointed blossom ends. These factors together explain the observed genetic dissimilarity, favoring the discrimination of this single accession concerning the others. 


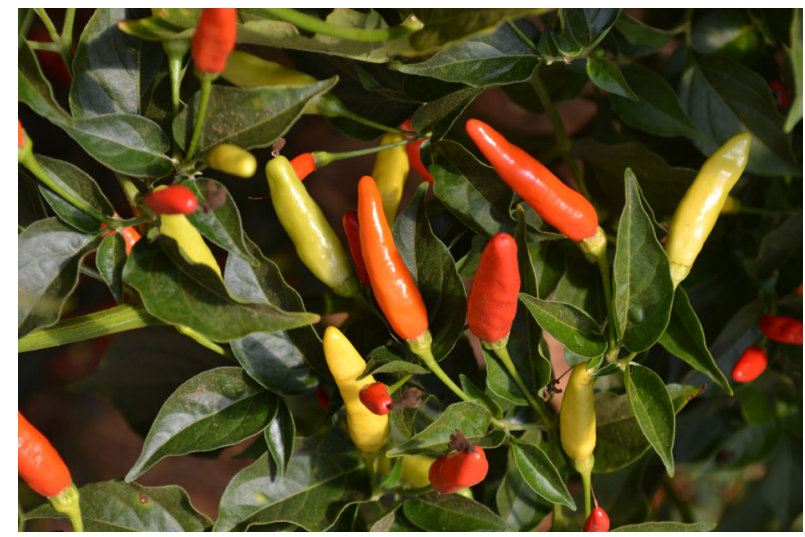

Figure 4. Capsicum frutescens fruits typical of the morphological type tabasco (accession CNPH 3861).

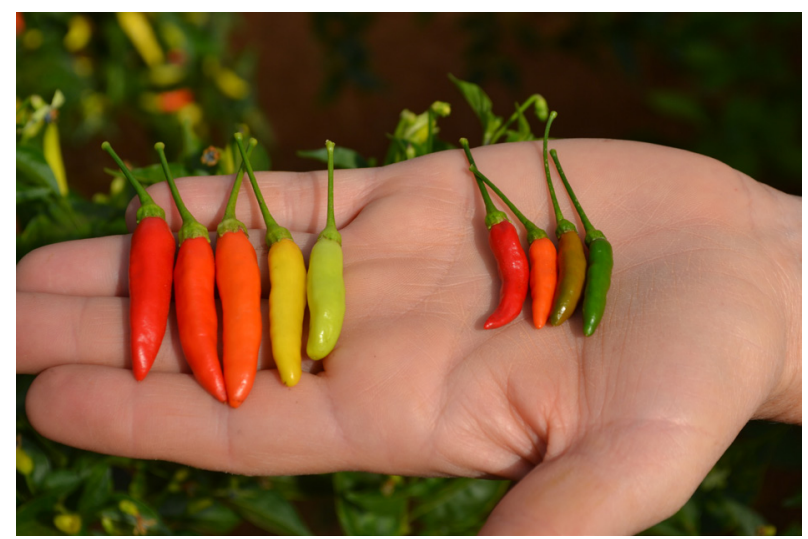

Figure 5. Capsicum frutescens fruits at different stages of maturity; on the left is the morphological type tabasco (accession CNPH 3861); on the right is the morphological type malagueta.

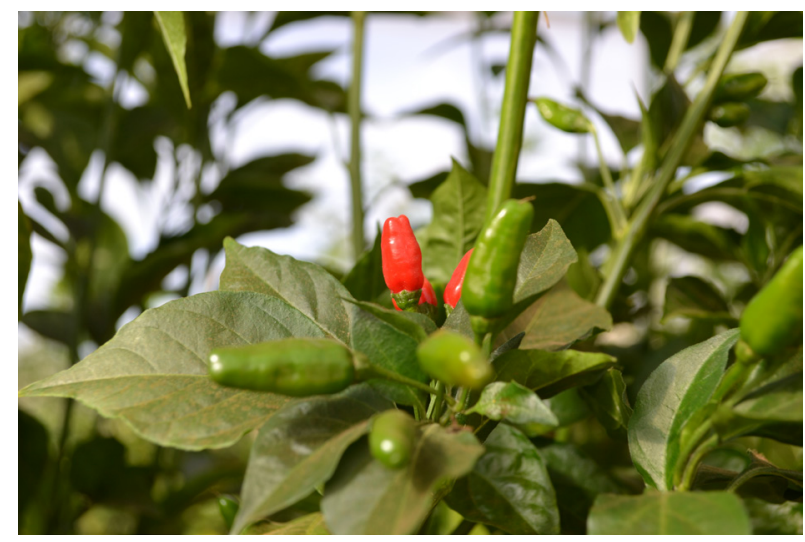

Figure 6. Capsicum frutescens fruits typical of the morphological type "malagueta", displaying a sunken blossom end shape (accession CNPH 3821).

Genetics and Molecular Research 16 (3): gmr16039689 


\section{DISCUSSION}

This study is the first in-depth characterization of such a large sample of the Brazilian C. frutescens germplasm, representing all Brazilian five geographic regions. Molecular and morphological characterizations carried out with this germplasm provide insight into the genetic variability of the $C$. frutescens in Brazil.

Twelve morphological descriptors were monomorphic (stem pubescence, leaf shape and pubescence, flower position, corolla and corolla spot color, calyx pigmentation, fruit blossom end appendage, neck at base of fruit, seed color, seed surface, and male sterility), i.e., invariable or unable to discriminate accessions within $C$. frutescens species, and thus could be eliminated in a future intraspecific characterization. Flower position is one of the minimum descriptors for $C$. frutescens selected by Silva et al. (2013), suggesting that these descriptors have discriminative capacity when applied to distinguish Capsicum species, but not accessions within C. frutescens. According to Baral and Bosland (2004), to differentiate among species of Capsicum, the inflorescence-related descriptors are essential, such as the flower position and the presence of calyx annular constriction, which are used to distinguish between $C$. frutescens and C. chinense. Qualitative descriptors related to reproductive parts are useful for the identification of Capsicum species, whereas intraspecific variability is best assessed by quantitative multivariate analysis based on the fruit length/width ratio, days to flowering and leaf, anther, filament and pedicel length (Ortiz et al., 2010).

In this study, genetic variability was mainly observed for quantitative traits, and the morphological descriptors with the highest degree of polymorphism were stem length and stem diameter, days to flowering, days to fruiting, fruit weight, fruit length, and fruit wall thickness. Jarret et al. (2007) evaluated fruit traits of 40 accessions of $C$. frutescens, including two accessions from Brazil, and observed a large variation of fruit length from 1 to $8.5 \mathrm{~cm}$, fruit width from 0.5 to $1.5 \mathrm{~g}$, and fruit weight from 0.18 to $4.04 \mathrm{~g}$. Barbosa et al. (2010) studied 182 pepper accessions of two C. annuиm subspecies (C. annuum var. annuиm and C. annuum var. glabriusculum) and two species, C. baccatum var. pendulum and C. frutescens, from Roraima, Brazil. Size (length and width) and weight of fruits of the 18 C. frutescens accessions studied had the lowest values compared to the other accessions, with an average of $1.7 \mathrm{~cm}$ in length, $0.48 \mathrm{~cm}$ in width and $0.30 \mathrm{~g}$ fresh mass.

Morphological characterization evidenced a similar morphological pattern among $C$. frutescens accessions, despite the variations observed especially among the fruits of malagueta and tabasco (Figure 5), and allowed the identification of 85 accessions of the morphological type malagueta (Figure 2), presenting erect, elongated, and red fruit, with 1.2 to $4.2 \mathrm{~cm}$ in length and 0.4 to $1.1 \mathrm{~cm}$ wide, fruit weight varying from 0.2 to $1 \mathrm{~g}$ and fruit wall thickness with a range of 0.3 to $1.3 \mathrm{~mm}$. The 14 accessions classified as tabasco differed from the morphological type malagueta by presenting fruit color transition beginning with light green, followed by yellow, orange, and light red to red (ripe fruit), fruit length ranged from 1.3 to $4.6 \mathrm{~cm}$ and fruit width from 0.5 to $1.4 \mathrm{~cm}$, fruit weight varied from 0.7 to $1.3 \mathrm{~g}$, and fruit wall thickness ranged from 0.2 to $1.2 \mathrm{~mm}$.

Morphological and molecular analyses were significantly correlated, although they presented a medium magnitude (0.6604), demonstrating the differences between the two types of characterization. Baba et al. (2016) found no significant correlation between the fruit morphological descriptors and amplified fragment length polymorphism molecular markers in C. chinense germplasm from different geographical regions of Brazil. The low magnitude or

Genetics and Molecular Research 16 (3): gmr16039689 
even the lack of correlation between the assessments should not be considered a limitation of these tools to quantify genetic variability. In contrast, the lack of correlation suggests that both types of characterization are important and play a complementary role in providing a better understanding and differentiation of the germplasm (Sudré et al., 2010; Oh et al., 2012).

Although molecular characterization showed genetic variability among and within the six established groups of $C$. frutescens, the formation of a large group (Group 2), with dissimilarity lower than 0.55 shows morphological and genetic similarity for most studied accessions. This finding leads to another issue, as previously observed by Smith and Heiser Junior (1951) among others (Pickersgill, 1971, 1984; Jarret et al., 2007) concerning the highly conserved morphological pattern of $C$. frutescens fruits. However, no logical explanation has been found for the origin of the $C$. frutescens conserved morphological pattern, in contrast to the wide variability expressed by other Capsicum species.

The dendrogram resulting from molecular data allowed a clear grouping of the $C$. frutescens types found in Brazil, specifically malagueta and tabasco peppers. There were questions regarding whether malaguetinha (Figure 3) constituted a varietal type of C. frutescens or whether the small fruits (results obtained from the four accessions studied ranging from 0.6 to $1.9 \mathrm{~cm}$ long, 0.3 to $0.7 \mathrm{~cm}$ wide, 0.14 to $0.4 \mathrm{~g}$, and fruit wall thickness from 0.3 to $0.6 \mathrm{~mm}$ ) were the result of a viral infection or rejection during the production process. However, a subgroup specific for the four malaguetinha accessions identified was established within Group 4 of the dendrogram (Figure 1), thus confirming its genetic identity, i.e., its identification as a morphological type within C. frutescens. Tabasco accessions were also clustered in Group 4, indicating the genetic proximity of this morphological type to malaguetinha.

Due to the visible difference between these two types of peppers, the inclusion of tabasco accessions in the same group as malaguetinha was not expected. Nine morphological characteristics displayed similar results between the fruits of the malaguetinha and tabasco subgroups: erect and elongated fruit presenting a slightly corrugated cross-section, low fruit persistence, two locules, placenta length greater than half of the fruit size, semi-wrinkled surface, strong pungency, and weak aroma.

Group 6 in the dendrogram (Figure 1) had accessions with the largest number of descriptors (19 morphological characteristics) with similar results, which contributed to making the group discrepant concerning the others. Additionally, this was the only group that showed some relationship to the geographical origin, with the highest proportion of accessions from the North region. Different from this result, the study by Finger et al. (2010) did not show a relationship between the geographic distance and the estimated diversity of 49 accessions of $C$. chinensis from Brazil. They reported that the diversity might be a reflection of genetic drift and plant selection in different environments rather than the geographic location. Another explanation is the occurrence of cross-pollination in a rate varying in Capsicum from 0.5 to $70 \%$, contributing to the genetic contamination of the seeds. Genotypes presenting characteristics that are unusual for $C$. frutescens are described and its putative position within species genetic variability (Figure 1) is reported. Namely, a subgroup in Group 2 of the dendrogram presenting orange and triangular fruits, and, in Group 3, accessions with fruits presenting pendant and intermediate positions, greater length, and increased fruit wall thickness. Moreover, Groups 2 and 3 had accessions that shared rare characteristics, such as calyx annular constriction, yellow and rectangular fruits.

Some of these characteristics are directly related to domestication practices, such as the human selection of fruits for increased wall thickness, greater length, and different

Genetics and Molecular Research 16 (3): gmr16039689 
colors (yellow and orange), corresponding to the original or wild plants, and the possibility of interspecific hybridization between C. frutescens and C. chinense, whether natural or artificial. This hypothesis was raised due to the presence of calyx annular constriction in C. frutescens genotypes (CNPH 3804, CNPH 3805, CNPH 3806, CNPH 3813, CNPH 3815, and CNPH 3818 ) since this characteristic is distinctive of the C. chinense species (Baral and Bosland, 2004). The presence of the calyx annular constriction mistakenly led the Embrapa Vegetable team to identify such accessions as $C$. chinense initially. However, they were all grouped together with $C$. frutescens specimens in the molecular analysis. Moreover, their passport data indicated proximity between $C$. chinense and $C$. frutescens cultivation fields, reinforcing the possibility of cross-fertilization.

The North, Northeast, and Center-West regions of Brazil may have played an important role in the genetic differentiation of $C$. frutescens. Accessions collected in the Amazon basin probably underwent incipient domestication by Amazonian indigenous populations, potentially with selection for plant populations that were adapted to different ecological conditions, but with no obvious alterations of the morphological pattern. Thus, accessions with different adaptive abilities are of extreme interest to breeding programs aimed at obtaining cultivars that are adjusted to different regions and farming systems in the country.

During the development of new pepper cultivars, a plant breeder should consider, in addition to the distance between accessions, adaptation to different farming systems, specific morphological characteristics of each varietal group, and the requirements and preferences of the market. The malagueta pepper market in Brazil includes the commercialization of fresh and dried fruits and fruits processed into preserves or liquid sauces (Ribeiro et al., 2008). The germplasm of $C$. frutescens evaluated in this study has considerable genetic variability that can be exploited for the development of new cultivars intended for different niche markets.

For the commercialization of fresh fruits, fruits with a larger size and weight and easy detachment of the calyx are preferred, for which the following accessions stood out in this study: CNPH 3649 (fruit length $=3.5 \mathrm{~cm}$; width $=1 \mathrm{~cm}$; fresh weight $=1.3 \mathrm{~g}$ ), CNPH 3944 (fruit length $=3.7 \mathrm{~cm}$; width $=1.1 \mathrm{~cm}$; fresh weight $=1.4 \mathrm{~g}$ ), and CNPH 4161 (fruit length $=$ $3.2 \mathrm{~cm}$; width $=0.8 \mathrm{~cm}$; fresh weight $=1.1 \mathrm{~g}$ ).

When processed into preserves, the fruits of malagueta pepper are used whole, so they should be suitable for packaging and have the desired commercial characteristics, i.e., small, resistant to cracks, free of spots, a deep red color, and good organoleptic properties (taste, aroma, and pungency). Furthermore, the fruit for the industry of preserves and sauces should be easily detached from the calyx (low persistence) to avoid injuries and darkening of the fruits after packaging and to avoid the additional step of peduncle removal. The presence of these characteristics for the production of preserves was found in accessions CNPH 2869, CNPH 3484, CNPH 3546, CNPH 3612, CNPH 3715, and CNPH 3894. Flesh firmness is also critical, but this characteristic has not been evaluated in this study.

One of the major routes of Capsicum pepper consumption in Brazil and worldwide is the liquid sauce. Peppers presenting larger fruits with a fleshy pulp, red color, and intense pungency are used. Malagueta and tabasco peppers, despite their small fruits, are used alone or in blends with other peppers in the preparation of highly spicy sauces (Ribeiro et al., 2008). For this niche market, the accessions CNPH 2631, CNPH 3499, CNPH 3630, CNPH 3645, CNPH3646, CNPH 3649, CNPH 3819, CNPH 3820, and CNPH 3944 were prominent.

Association of morphological and molecular characterization provided knowledge on the variability of $C$. frutescens accessions representing the Brazilian diversity of $C$.

Genetics and Molecular Research 16 (3): gmr16039689 
frutescens. This study showed genetic variability that can be used for developing cultivars for different market niches. Three morphological types were confirmed: malagueta, tabasco, and malaguetinha. This study confirmed that $C$. frutescens has highly preserved morphological characteristics and this needs to be further studied and possibly different hypothesis formulated, invoking domestication, artificial selection, and other anthropogenic elements.

\section{ACKNOWLEDGMENTS}

Research supported by Universidade de Brasília (UnB), Embrapa (Brazilian Agricultural Research Corporation), and the National Concil for Science and Technology Development (CNPq).

\section{REFERENCES}

Baba VY, Rocha KR, Gomes GP, Ruas CF, et al. (2016). Genetic diversity of Capsicum chinense accessions based on fruit morphological characterization and AFLP markers. Genet. Resour. Crop Evol. 63: 1371-1381. https://doi. org/10.1007/s10722-015-0325-4

Baral JB and Bosland PW (2004). Unraveling the species dilemma in Capsicum frutescens and C. chinense (Solanaceae): a multiple evidence approach using morphology, molecular analysis, and sexual compatibility. J. Am. Soc. Hortic. Sci. 129: 826-832.

Barbosa RI, Luz FJF, Nascimento Filho HR and Maduro CB (2002). Pimentas do gênero Capsicum cultivadas em Roraima, Amazônia Brasileira. I. Espécies domesticadas. Acta Amazon. 32: 177-192. https://doi.org/10.1590/180943922002322192

Barbosa RI, Mourão Júnior M and Luz FJF (2010). Morphometric patterns and preferential uses of Capsicum peppers in the state of Roraima, Brazilian Amazonia. Hortic. Bras. 28: 477-482. https://doi.org/10.1590/S0102$\underline{05362010000400017}$

Buso GSC, Reis AMM, Amaral ZPS and Ferreira ME (2016). Novel and highly informative Capsicum SSR markers and their cross-species transferability. Genet. Mol. Res. 15: gmr.15038689.

Carvalho SIC, Ragassi CF, Bianchetti LB, Reifschneider FJB, et al. (2014). Morphological and genetic relationships between wild and domesticated forms of peppers (Capsicum frutescens L. and C. chinense Jacquin). Genet. Mol. Res. 13: 7447-7464. https://doi.org/10.4238/2014.September.12.11

Carvalho SIC, Ragassi CF, Oliveira IB, Amaral ZP, et al. (2015). Transferability of microsatellite markers of Capsicum annuum L. to C. frutescens L. and C. chinense Jacq. Genet. Mol. Res. 14: 7937-7946. https://doi.org/10.4238/2015. July.17.1

DeWitt D and Bosland PW (2009). The complete chile pepper book: a gardener's guide to choosing, growing, preserving, and cooking. 1st edn. Timber Press, London.

Eshbaugh WH (1980). The taxonomy of the genus Capsicum. Phytologia 47: 153-166. https://doi.org/10.5962/bhl. part.4455

Finger FL, Lannes SD, Schuelter AR, Doege J, et al. (2010). Genetic diversity of Capsicum chinensis (Solanaceae) accessions based on molecular markers and morphological and agronomic traits. Genet. Mol. Res. 9: 1852-1864. https://doi.org/10.4238/vol9-3gmr891

IPGRI (International Plant Genetic Resources Institute) (1995). Descriptors for Capsicum (Capsicum spp.). IPGRI, Rome.

Jarret RL, Baldwin E, Perkins B, Bushway R, et al. (2007). Diversity of fruit quality characteristics in Capsicum frutescens. HortScience 42: 16-19.

Nagy I, Stágel A, Sasvári Z, Röder M, et al. (2007). Development, characterization, and transferability to other Solanaceae of microsatellite markers in pepper (Capsicum annuum L.). Genome 50: 668-688. https://doi.org/10.1139/G07-047

Oh SJ, Song JY, Lee J, Lee GA, et al. (2012). Evaluation of genetic diversity of red pepper landraces (Capsicum annuum L.) from Bulgaria using SSR markers. Korean J. Intl. Agri 24: 547-556. https://doi.org/10.12719/KSIA.2012.24.5.547

Ortiz R, De La Flor FD, Alvorado G and Crossa J (2010). Classifying vegetable genetic resources - A case study with domesticated Capsicum spp. Sci. Hortic. (Amsterdam) 126: 186-191. https://doi.org/10.1016/j.scienta.2010.07.007

Pickersgill B (1971). Relationships between weedy and cultivated forms in some species of chili peppers (genus Capsicum). Evolution 25: 683-691.

Genetics and Molecular Research 16 (3): gmr16039689 
Pickersgill B (1984). Migration of chili peppers, Capsicum spp, in the Americas. In: Pre-Columbian Plant Migration (Stones D, ed.). Harward University Press, Cambridge, 106-123.

Pickersgill B, Heiser CB and McNeill J (1979). Numerical taxonomic studies on variation and domestication in some species of Capsicum. In: The biology and taxonomy of the Solanaceae (Hawkes JG, Lester RN and Skelding AD, eds.). Academic Press, London, 679-700.

Rêgo ER, Finger FL and Rêgo MM (2012). Types, uses and fruit quality of Brazilian chili peppers. In: Spices: Types, Uses and Health Benefits (Kralis JF, ed.). Nova Science Publishers, New York, 131-144.

Ribeiro CSC, Lopes CA, Carvalho SIC, Henz GP, et al. (2008). Pimentas Capsicum. Embrapa Hortaliças, Brasília.

Smith PG and Heiser Junior CB (1951). Taxonomic and genetic studies on the cultivated peppers, Capsicum annuum L. and C. frutescens L. Am. J. Bot. 38: 362-368. https://doi.org/10.2307/2437824

Silva WCJ, Carvalho SIC and Duarte JB (2013). Identification of minimum descriptors for characterization of Capsicum spp. germplasm. Hortic. Bras. 31: 190-202. https://doi.org/10.1590/S0102-05362013000200004

Sudré CP, Gonçalves LSA, Rodrigues R, do Amaral Júnior AT, et al. (2010). Genetic variability in domesticated Capsicum spp as assessed by morphological and agronomic data in mixed statistical analysis. Genet. Mol. Res. 9: 283-294. https://doi.org/10.4238/vol9-1gmr698

Genetics and Molecular Research 16 (3): gmr16039689 